\title{
From the Caucasus to USA: Dagestani Islamic Manuscripts in Princeton University ${ }^{1}$
}

\author{
Magomed Gizbulaev Institute of History, Archaeology and \\ Junior Research Fellow Ethnography Dagestan Scientific Center \\ Department of Ancient and Medieval Russian Academy of Sciences, \\ History of Dagestan Moscow, Russia
}

\begin{abstract}
This article describes the Dagestani Islamic manuscripts collection of Imam Shamil's library, housed in Firestone Library of Princeton University in the Garrett Yahuda Collection. It is the purpose of this paper to present a sense of the Arabic literary culture in the Caucasian region. The material based here, on nineteen original scholarly works of Dagestani authors from the 12th to the 19th centuries, allows us to reveal how a longstanding Islamic intellectual culture played an important role in the emergence of original scholarly works of local authorship.

One more specific feature of the epistolary tradition that must be taken into consideration is, that a considerable portion of Dagestan's cultural heritage existed in the form of Arabic and Ajamic manuscript collections that were destroyed by the Soviet regime in its significant efforts to make the mountainous people really "unwritten" under the slogan of fighting with imaginary nationalism and Islamic "backwardness."
\end{abstract}

Keywords: Islamic manuscripts, Princeton University, Dagestan, Genres, library, Imam Shamil, Ajam

\section{Introduction}

The mild winter, lovely parks, tree-lined streets, restaurants, specialty shops and the friendly and safe atmosphere of Princeton, New Jersey, USA, makes the town a wonderful area for the local residents and numerous visitors. An excellent transportation network of bus, railway and highway is not Princeton's only advantage. Among the various benefits of the town, special mention must be made of Princeton University which is spread on 500 acres; a historic campus in itself with many amenities available. When I first visited Princeton University in the fall of 2010, I found the beauty and simplicity of the place to be unreal. All over the campus, squirrels were freely roaming around, and the well-cared for Prospect House Garden rounded off the first impression of a fabulous place.

The Firestone Library is one of Princeton University's great assets, ${ }^{2}$ and is also one of the world's most distinguished research libraries. Since its founding more than 240 years ago, the library system at Princeton has grown from a collection of 474 volumes in one room of Nassau Hall to over 11 million holdings in 19 buildings throughout the campus.

\section{Dagestani Islamic Manuscripts in the Firestone Library}

Islamic manuscripts offer researchers a wealth of information on a culture and civilization that is often misunderstood. Thus, the objective of this article is to 
present a sense of the Arabic literary culture in the Caucasian region. Through this paper of selected manuscripts, I hope to convey an impression of the distinctiveness and richness of the diversity of thematic content and types of Arabic and Ajam (Avar language), the creation and circulation of scholarly works, treatises, tracts, the production of correspondence in Arabic, and the practices of reading. The Caucasian Arabic manuscripts at the Department of Rare Books and Special Collections, Princeton University Library, ${ }^{3}$ known as the Yahuda Section of Robert Garret's (Class of 1887) ${ }^{4}$ Arabic manuscripts, were catalogued by Rudolf Mach. ${ }^{5} \mathrm{He}$ counted at least 130 manuscripts with the word "Shamil"'. In this research, I have, using Shamil's library, examined nineteen original scholarly works of Dagestani authors from the $18^{\text {th }}-19^{\text {th }}$ centuries. Apart from the manuscripts with the word "Shamil," four manuscripts composed by the local authors, dating back to the $12^{\text {th }}$ and $15^{\text {th }}$ centuries, have been discovered and reflected upon in this article.

A secondary aim of this study is to demonstrate how a long-standing Islamic intellectual culture played an important role in the emergence of original scholarly works of local authorship. Despite recent changes in Islamic and Arabic Studies in Russia, the heritage of Dagestan's Arabic manuscript culture has not yet sufficiently been studied, largely because it requires good knowledge of Arabic language and history of Islamic intellectual culture. There is relatively little written about translation, analysis and commentaries of Dagestan Arabic scholarly works in Russian Caucasian studies space. ${ }^{7}$ I myself published a monograph on the Arabic scholarly legacy of the prominent $18^{\text {th }}$ century Dagestani scholar, Abu Bakr al-Aimaki. ${ }^{8}$ Characterizing foreign literature, I would highlight works by M. Kemper. ${ }^{9}$

Almost all literature and correspondence was composed in Arabic by Dagestan scholars who had, throughout centuries, been in intensive cultural and scholastic exchange with the broader Muslim world. One more specific feature of Muslim culture in Dagestan that must be taken into consideration is that a considerable portion of Dagestan's cultural heritage exists in the form of Arabic manuscript collections located in various Russian and foreign institutes and university libraries such as those of Institute of History, Archaeology and Ethnography of the Dagestan Scientific Center of the Academy of Russian Sciences (more than 5000 manuscripts), Dagestan State University Library, Institute of Oriental Manuscripts in Saint Petersburg, at least 400 mosques and private libraries in Dagestan, Princeton, Jerusalem, Michigan, British Manuscript Library, Institute of Oriental Studies in Tbilisi, etc. Political and social developments in the latter part of the $19^{\text {th }}$ and beginning $20^{\text {th }}$ centuries encouraged an outflow of scholars and Arabic libraries from Dagestan.

\section{Academic Interests of Scholars in the Pre-Soviet Dagestan}

During the spread of Islam, there was a process of entrenchment of scientific literature of the Muslim world which has been developed and evolved at the schools of Basra, Kufa, Baghdad, Medina, Cairo and a number of academies in various corners of the Caliphate. Dagestan's own scholars achieved renown 
throughout the Muslim world for their Arabic literary tradition. ${ }^{10}$ Their academic interests overarched a broad range of contemporary research areas in respective periods such as the Quran and Hadith, poetry and rhetoric, usul al-figh (the theory of law) and aqidah (the creed), astronomy and algebra, Arabic grammar and calligraphy, history and sirah (the biography of the Prophet Muhammad), politics and ethics, medicine and pharmacology. There are analyses of the collection produced in the form of articles with illustrated samples of manuscripts, names of scholars which are important historical documents for the studying of Dagestani social, political, legal and educational history.

The imperial Russian and succeeding Soviet tradition of historiographies and Islamology ignored the impact of Islam in the formation of literary culture and organization of educational system prior to the Soviet era. Accounts of modern Caucasian studies both in Russia and Western Europe have been dominated by approaches based on the view which relegate the Caucasians as violent people and insurgents, and who were isolated from the Islamic centers of the Muslim world. "The study of the North Caucasus is marred by thin stereotypes and onesided perspectives." 11

There is a widespread and rather misleading notion of the persistence of Sufism within Dagestani Islamic intellectual culture among Russian as well as Western historians. Materials related to the dominance of Sufism in pre-Soviet Dagestan allow us to re-consider this misleading notion. It is noteworthy that by studying collections of Arabic manuscripts of Dagestani leading scholars of the $18^{\text {th }}$ and $19^{\text {th }}$ centuries such as Muhammad b. Musa al-Qudutli (d.1717), Dawud al-Usisha (d.1757), Abu Bakr al-Aimaki (d.1791), Hasan al-Kabir (d.1795) and 'Umarjan (d.1801) al-Kudali, Said al-Harakani (d.1834), Murtaza 'Ali al-'Uradi (d.1865), Muhammad Tahir al-Qarakhi (d.1880), Zaghalaw al-Khwarshi, Hasan Afandi alQadari (d.1910) and many other scholars, we witness the absence of Sufi discourse in their creative and scholarly activity. Moreover, in the course of the Great Caucasian War "there was no clear-cut position of the Khalidiyya (Sufism) on the question of jihad even during the era of Imams." 12

Today, one can find a few scholars in Dagestan who still write in the Dagestani naskh, Arabic script, distinctive of the region. Our written heritage embodies the precious symbols of the Caucasian Muslim Culture. The very roots of Dagestani cultural identity are being revived by studying and publishing Islamic manuscripts of local scholarship. As we see it at the moment, the paper will definitely have an impact on research among academic historians, social anthropologists, orientalists, and others who are engaged in the study not just of Caucasian history but also the history of the Middle East and Islam in general.

\section{A Description of the Manuscripts}

Judging by the size, script, autograph and content of the collection in Princeton University Library, Caucasian Arabic manuscripts were mostly from $210 \times 170$; $158 \times 105 \mathrm{~mm}$ to $270 \times 177 ; 210 \times 130 \mathrm{~mm}$, copied in Dagestani $n a s k h$, autographs 3 and with a focus on figh. This group of works contains authors of Shafi $i$ madhab such as Muhyi Din al-Nawawi (d.1277), Yusuf al-Ardabili (d.1396), 
Jalal ad-Din as-Suyuti (d.1505), Ibn Hajar al-Haythami (d.1567). In the Dagestani legal literary tradition as well as in the Muslim world at large, there were popular commentaries and glosses on works written by authoritative jurists. For instance, the renowned Egyptian jurist 'Abd Allah ibn Hijazi ibn Ibrahim alSharqawi (d.1812) wrote commentaries on Mukhtasar of "Ali al-Kabir alDagestani (d.1538).

We have substantial data on volumes and tracts to outline the information: authorship, ownership, titles, content, genre, size, number of folios and dating in most cases. There are general considerations to bear in mind as we look at the texts.

A genre of writing that was highly valued in Dagestan was compendium, abridgements and fatwa in Islamic Law. Driven by the desire to render the Sharia teachings adaptable to the complex demands of contemporary Dagestani life, local scholars were particularly interested in the spheres of social relations. Political, military and cultural conflicts in the Caucasus all played significant role in scholars' lives. The titles of legal manuscripts of the Caucasian scholarship represented in this paper include eight works from the $15^{\text {th }}-19^{\text {th }}$ centuries. 1) alFuru' al-nafisah 'ala l-Minhaj; 2) Dalail al-Minhaj min kalam Rabb al-'alamin wa-sunnat Sayyid al-mursalin; 3) Sharh al-Mukhtasar al-Daghistani; 4) alMafrud 'ala muaddi l-furud; 5) I'-lam at-Tilmidh bi-ahkam al-nabiz; 6) Durrat an-Nafisah; 7) Rislalah as-Shareifah; 8) Ajwibah 'an as'lat Mahdikhan Shamkhali.

The al-Furu' al-nafisah 'ala l-Minhaj (The Book of the Beneficial Cases found in Minhaj) (MS Garrett Yahuda 3667/Mach 1435) is a commentary on legal cases derived from the Minhaj at-Talibin by the Shafi' $i$ jurist Yahya b. Sharaf alNawawi. It was written by Sheikh Imam 'Abd al-Malik b. 'Ali b. Abi al-Muna al-Babi al-Halabi al-Shafi'i (d.1435), known as 'Ubeid, a grandson of al-Bab alAbwab (Derbend) ${ }^{13}$ scholar who moved to Halab (Syria). The signature of the alFuru' al-nafisah 'ala l-Minhaj is not yet clear. But we do know that one of its two volumes al-Furu' al-Shafi'iyah (MS Garrett Yahuda 2579/Mach1435) had been copied in the author's period; yet the first volume is incomplete at the end. The second copy of the textbook is a huge composition of $201 \mathrm{ff}$. and size $272 \times 183 ; 200 \times 128 \mathrm{~mm}$. This kind of legal work of the Imam 'Abd al-Malik b. 'Ali b. Abi al-Muna al-Babi was not the only one composed throughout his creative activity.

There was another work of the author, called Dalail al-Minhaj min kalam Rabb al-'alamin wa-sunnat Sayyid al-mursalin (The Book of Minhaj Arguments Derived from the Book of the Master of Universe (Quran) and Tradition of the Head of Messengers (Sunnah) (MS Garrett Yahuda 3667/Mach 1435). This is a detailed commentary on the Minhaj al-Talibin of 196 ff. size 278×186; $195 \times 128 \mathrm{~mm}$ and was copied in 1457 . An examination of these three unpublished commentaries/manuscripts of 'Abd al-Malik al-Babi shows that Shafi'i madhab gained its authority in the region and how commentary genre functions to define and perpetuate the identity of madhab. Moreover, they may be the earliest extant known manuscripts of Islamic Law in the Caucasus. Remarkably comprehensive, 
they elucidate profoundly Minhaj al-Talibin with respect toward its author, alNawawi and add a new segment to adapt traditional legal cases to new circumstances. Yet the Dalail al-Minhaj min kalam Rabb al-'alamin wa-sunnat Sayyid al-mursalin is a highly creative and independent work, and its method of making legal arguments is quite different than that found in the Minhaj alTalibin. Its legal topics/cases are arranged in a distinctive manner- kitab-bab-fasl, which are substantiated by arguments from the Quran and Sunnah in terms of their linguistic and legal contexts, the Prophet's companions' consensus, and authoritative scholars' opinions of the different madhabs. These unpublished commentaries show that being a Shafi'i faqih is not a matter of imitating alNawawis' opinions but rather suggest rulings and statements taking into account a respective period and place.

One of the earliest examples of the abridgment genre of the Shafi'i madhab in the Caucasus was al-Mukhtasar of 'Ali al-Kabir b. Muhammad al-Dagestani (d.1538) who designed it as a textbook for the incipient legal curricula in the region. As is common with fiqh summary texts, the textbook generally does not make a point of providing evidences and derivations of the regulations. The traditional method of learning is for young people to first study a basic jurisprudence, then later go back and study each issue in more detail. The Egyptian jurist 'Abd Allah ibn Hijazi ibn Ibrahim al-Sharqawi (d.1812) on the request of his peer jurist Muhammad Afandi, known as Shafi'i al-Dagestani, commentated on Sharh 'ala l-Mukhtasar al-Dagestani (Commentary on the Compedium of Dagestani) (MS Garrett Yahuda 3135/Mach 1696). He is using four distinct colors (red, green, yellow and orange) to underline when quoting the entire verbatim, phrase by phrase and explains in detail 'Ali al-Kabir's statements recorded in the Mukhtasar, providing interpretations of the Quran, Sunnah and citing authorities' opinions. The volume Sharh 'ala al-Mukhtasar al-Dagestani represents an autograph which was composed by al-Sharqawi in 1784 and comprised of $138 \mathrm{ff}$. size $216 \times 175 ; 145 \times 103 \mathrm{~mm}$.

The fundamental character of the Sharia is its address to the individual, i.e., the person who is obligated, forbidden, exhorted. Based on the nature of mankind, knowledge has a dual nature: (a) Fard al-'Ayn and (b) Fard al-Kifayah. Fard'Ayn includes the obligatory knowledge of the pillars and tenets of Islam and the basic knowledge of Sharia by the true believer. In view of the importance of Fard al-'Ayn, the prominent Dagestani scholar Muhammad Tahir al-Qarakhi (d.1880) produced a legal composition al-Mafrud 'ala muaddi al-furud min 'ilm atTawhid wa rubi' al-'ibadah (The Obligatory Knowledge about the Concept of the Oneness and Worship Required to know by an Incumbent) (MS Garrett Yahuda 1177/Mach 1698). The author presents a complete commentary on the fundamental creed/legal acts and interpersonal relations that shaped the text, and explains the tenets of Islamic belief. The textbook provides an important Sharia background for the Muslim students in the Caucasus. It was written at the request of Imam Shamil's naib Daniyal-Bek al-Elisu (d.1872). ${ }^{14}$ The size of the volume is $178 \times 111 ; 155 \times 71 \mathrm{~mm}$ and comprises of $65 \mathrm{ff}$. 
The analysis of the faqih Abu Bakr al-Aimaki's (d.1791) work I'lam at-Tilmiz bi ahkam an-Nabiz (Notification to a Student with regard to the Statements on Millet Beer) (MS Garrett Yahuda 5080/Mach 2090) shows that the use of alcohol is incompatible with the requirements of Sharia. The author from Dagestan composed it in 1777 with the objective to show students the problematic questions, in particular, the discrepancy of opinions of some scholars concerning nabiz millet beer. Clarifying each problem, the lawyer refers to citations from the Quran, Hadith and statements of the authoritative Muslim jurists. The aim of the treatise is to eradicate tradition of some people, particularly a few scholars, in Dagestan who used to drink a sort of alcohol called nabiz. According to Abu Bakr al-Aimaki, nabiz is a sort of wine. The size of the manuscript is $220 \times 176$; $192 \times 130 \mathrm{~mm}, 22$ lines on the page and comprises of $6 \mathrm{ff}$.

A fatwa is an opinion given by an acknowledged expert on Islamic Law on a particular topic from the point of view of the Sharia. The fatwas present a picture of different issues and ideas that provide insight into the tension between ideal and daily practices. The remaining two legal treatises Durrat al-nafisah of Murtaza 'Ali al'Uradi (d.1865) and Risalah al-Shareifah of 'Abd Rahman alThughuri (d.1882) focus on the state of Muslims after invasion of the Caucasus by the Russian Empire which ended with the annexation of the areas of the North Caucasus to Russia in 1864. The Caucasian Imamate's qadi Murtaza 'Ali al'Uradi attempts to provide more adequate understanding of the notion of hijrah (a temporary settlement from Dar al-Kufr to Dar al-Salam) that was often misperceived and unevaluated by some intellectuals and ignorant countrymen who showed their allegiance to the disbelieving conquerors. The treatise Durrat al-nafisah (The Precious Pearl) (MS Garrett Yahuda 2867/Mach 2034) listed opinions of the authorities of Sharia, classified the territories and also defined social circumstances in making his legal argument in favor of hijrah. The size of the manuscript is $215 \times 170 ; 155 \times 120 \mathrm{~mm}, 16$ lines and comprised of $5 \mathrm{ff}$.

Another acknowledged Dagestani scholar 'Abd Rahman al-Thughuri composed a similar treatise Risalah al-Shareifah (The Noble Message) (MS Garrett Yahuda 2867/Mach 2034) treating the issue of hijrah where he advocates the opinion that, following the Russian implemented policy of prohibiting Sharia practices in the Muslim Caucasus, it was incumbent upon Muslims to perform the hijrah. This approach of Islamic Law to the hijrah revealed an understanding of international relations focusing on the status of Muslim territory conquered by non-Muslims. The size of a treatise is $4 \mathrm{ff}$. and copied within the volume of distinctive titles.

This collection of the Dagestani judicial writings treats a wide range of problems faced by the Caucasian Muslims, from aspects of belief and worship to social relations. The spheres of social relations include commercial matters, marriage, inheritance, health, family issues, political and inter-religious relationships. The cases covered in the manuscripts reflect practices that are typical of certain parts of the Caucasus and can be classified as furu' al-fiqh (the practice of law). Fiqh is based on several sources, the most important being the Quran and Hadith. 
Hadith writings represent another theme of the Dagestani manuscripts. The Sharh al-Shihab (Commentary on Shihab) (MS Garrett Yahuda 3402/Mach 619) of Abu Bakr b. Musa b. al-Faraj al-Babi (d. XII) is a commentary on Kitab Shihab al-Akhbar fil hikam wal amthal wal adab minal al-ahadith al-Nabawiya of Abu 'Abdullah Muhammad al-Quda'i (d. 1062). The advantage of this composition in Hadith genre comes out clearly in the original method which Abu 'Abdullah al-Quda'i followed in his study of prophetic proverbs. The Dagestani author delves into great detail and depth in his commentary on the Hadith. Every proverb of the Prophet is studied linguistically, logically, legally and so on. The 'allamah al-Babi Abu Bakr b. Musa uses his vast knowledge of the classical Arabic to put before the reader almost all that the author of Shihab had to say on matters related to the Hadith-proverbs. This gives the reader a chance to penetrate the essence of these prophetic proverbs and to familiarize one with their reasoning and wisdom. The text of the manuscript consists of $117 \mathrm{ff}$. a format $203 \times 144 ; 138 \times 90 \mathrm{~mm} .16$ lines.

Throughout the history of Islam, the Quran and the Hadiths have functioned together to shape the life of the community worldwide. Hadiths provide the basic sources for the sirah of the Prophet Muhammad $(S A W)$, filling in details regarding events mentioned briefly in the Quran and providing a wealth of information on the personality, family and career of the Prophet $(S A W)$.

A work that was highly valued was Mankhul Maghazi (The Chosen Campaigns) (MS Garrett Yahuda 3133/Mach 4549), written in a Sirah genre with the Prophet Muhammad's $(S A W)$ selected campaigns supplemented with detailed episodes of the history of Khulafa ar-Rashidin (the four Rightly Guided Caliphs) and their Umayyad successors produced by the Dagestani scholar Hasan al-Kabir alKudali (d.1795). The great value for the emergence of Mankhul Maghazi had compositions of scholars from the Muslim world, such as both Sahih al-Bukhari and Muslim, Sirah written by Sheikh 'Ali al-Halabi al-Shafi'I, etc. Hasan alKudali composed his work with the aim to learn and know the Prophet's features, qualities and noble acts in the course of campaigns and on battlefields.

The Mankhul Maghazi gained crucial interest during the Caucasia War in the $19^{\text {th }}$ century among the Dagestani ghazis (warriors) who resisted the Russian encroachment in the Caucasus. The mountaineers believed that by following the ideal example set by Muhammad $(S A W)$, the prosperity of a society is guaranteed. We have two volumes of Mankhul Maghazi copied in the $19^{\text {th }}$ century in Imam Shamil's library at Princeton Firestone Library. The Sirah composition consists of $80 \mathrm{ff}$. with a format of $210 \times 170 ; 152 \times 105 \mathrm{~mm}, 14$ lines. 




Opening page of Mankhul Maghazi, a Sirah book, with the information containing the name of the author and the solicitor: 'Uthman b. Bughdan al-Qumuqi

Another genre of writing which contributes serious scholarship is the Aqidah (the creed) genre. The Caucasian Islamic Manuscripts Collection at Princeton Library has one manuscript Muhimmat al-ma'arif al-wajibah 'ala l-'ibad fi umur almuta'alliqah bil mabda' wal ma'ad (The Obligatory Knowledge upon Servants about Issues pertained to the Present World and Hereafter) of 'Ali b. Ibrahim alDagestani (d.18 ${ }^{\text {th }}$ century) (MS Garrett Yahuda 3828/Mach 2574). The textbook acquaints students with the basic beliefs and teachings of Islam, which every Muslim is obliged to know, in a simple and engaging manner. It contains many explanatory charts and eight chapters with respective paragraphs on Allah's attributes, the creed of the four Imams, the signs of Doomsday, Paradise and Hell, the Day of Reckoning, etc. The interesting question is not how 'Ali b. Ibrahim arrived in Medina from Dagestan in the first place, but how he became an acknowledged Hanafi scholar among Medines, whereas members of the intellectual elite in Dagestan were representatives of the Shafi'i madhab. This is an autograph of 'Ali b. Ibrahim al-Dagestani which had been written in 1700 . The volume comprises of $200 \mathrm{ff}$. a format $207 \times 148 ; 155 \times 95$, 21 lines.

Apart from Aqidah literature, Dagestani scholars were also interested in political thought. The al-Jawahir al-rafi'a fi Haqqiyyat Madhab ahl al-Sunnah wa-radd shubuh al-Shi'a (The Lofty Jewelry in the Truth of Ahl al-Sunnah, and Refutation of the Shia Ambiguity) written by Said al-Harakani's (d. 1834) (MS Garrett Yahuda 2867/Mach 2645) focused on the study of political leadership in Islam. The main issues covered in the treatise are how a person should be elected, the conditions of legitimacy, and the role of a successor. Different answers, in the author's opinion, to these questions have led to divisions in the Muslim Ummah, mainly between Shi'a and Sunni. The work in political thought treats the legitimacy of the reigns of the Khulafa ar-Rashideen and their successors, yet Said al-Harakani produces explicit arguments which undermine the Shi'a political doctrine. According to the Shī'is, an Imam can't be elected and has to be 
nominated by God. By contrast, Sunnis believe that their Imams were popular and had greater vote so they were made Caliphs. The manuscript is written in 48 ff. length in a format of 215 170; $155122 \mathrm{~mm}, 19$ lines. Moreover, there are two tracts incorporated within the aforementioned volume with distinct titles: Ajwibah 'an as'ilat al-Derbendi and "Ajwibah 'an as'ilat Mahdi Khan alShamkhali” of Said al-Harakani.

The works of writing that were highly valued in Dagestan were what are now called Islamic ethics. There are multiple copies of such works from later periods of the pre-Soviet in Caucasian Arabic scholarship, kept in private and academic manuscript libraries in Dagestan. According to the catalogue of Arabic manuscripts in Princeton, there are two treatises of Dagestani authors of this genre in the library there. The treatise "Nuskhah jadidah fil umur al-muhimmah" (MS Garrett Yahuda 4190/Mach 2036) was composed to educate believers and instill in them pious conduct and profound sense of the shahadah (witness of the Oneness of God and Muhammad, His servant and Prophet), enjoining what is good, forbidding what is evil, the ways of ritual purification, performance of prayers, etc. The unknown author of the manuscript largely based it on sources of classical scholarship, particularly "Ihya "Ulum al-Din" of al-Ghazali (d.1111). Physical details of the composition in ethics: 20 lines, $157 \mathrm{ff}$., $179 \times 110 ; 140 \times 72 \mathrm{~mm}$.

The other one with similar theme in a collective volume is the Kitab ilm alfaraiz thumma al-Munabbihat qissah 'an al-Mi'raj thumma bayan al-Asrar (The Book of Mandatory Knowledge) copied by Isa b. Musa b. Isa al-Ihali (MS Garrett Yahuda 2308/Mach 2037). The textbook has been divided into four parts with an aim to emphasize the importance of teaching and adequate awareness of the fundamentals of Islam which are Tawheed, Iman, Ibadah, and to develop the readers' knowledge of the Prophet's Mi'raj (ascendance), and appreciate and practice the teachings of his Sunnah. Apart from the mentioned topics there is a part in the treatise that addresses the question of how to teach people Islamic manners and etiquette in relation to themselves and all others.

If we were to construct a continuum from 'high' to 'low' and locate the manuscripts on it, then poetry and prosody would be on the high end after Islamic Law. Religious prose and poetic writings were highly valued in Dagestan in the $18^{\text {th }}-19^{\text {th }}$ centuries. The context of the texts addresses the reader to exercise strictly all injunctions of Allah, to imitate in daily life the virtues of the Prophet Muhammad ( $S A W$ ), and to withhold from committing grave sins kabair.

The research interest presents a poem al-Takhmis a'la lil qasidah al-'ulya of 'Abbas Fawzi Afandi al-Dagestani (d.?) (MS Garrett Yahuda 3040/Mach 4228). The author expresses through his poem (qasidah) love, honor and praise for Allah, the Prophet Muhammad ( $S A W)$, his companions, the four Imams, Quran, etc. in his verses. The poetry work is an autograph and it has very long verses 18 ff. $226 \times 154 ; 160 \times 95,15$ lines. While the other Dagestani poet Said al-Harakani devoted his poetic work al-Manzumah fil al-kabair (The Poem on Major Sins) (MS Garrett Yahuda 5438/Mach 2033) to remind people to abstain from major sins which have been forbidden by the Quran and Sunnah and replace them with 
virtues which have been made clear by the actions of the Prophet Muhammad $(S A W)$ and his companions. The didactic poem of Said al-Harakani can be attributed to a mathnawi genre. The Caucasian Arabic literature tradition has never ceased to produce poetry that can be called devotional. Another volume contains poems, as shown by the colophon, written by Muhammad Kamil Afandi, the son of Imam Shamil in the month of Shawal, 1887, in Medina where Shamil settled with his family after he was allowed to leave Russia in 1870.

Muhammad Kamil's qasidahs Qasidah Munajat al-Imam Shafi'i (Talking in Secret with Imam al-Shafi'i) and Qasidah ya Rasulillah (MS Garrett Yahuda 1069/Mach 4162) were written by him at the age of 12. These poetic writings represent a brilliant sample of the Dagestan Arabic written verse-building which once again confirms that local intellectuals were very familiar with many compositions of poets of the Muslim world. Finding the correct forms of versification could be done by the prosody knowledge. This entailed the production of numerous textbooks in lingual science in Dagestan, for instance Risalah fi 'ilm al-'Arud (The Tract on Prosody) (MS Garrett Yahuda 5206A/Mach 3856) compiled in 1783 by Muhammad b. Dibirilaw al-Harakani. The treatise addresses the study of poetic metres to define which is correct or incorrect and the metre units in the Arabic poetry system, especially metre, that contribute to rhythmic effects in poetry. The handwriting is accurate; it consists of $20 \mathrm{ff} .210 \times 163 ; 158 \times 103 \mathrm{~mm}, 15$ lines.

It was a central part of the pre-Soviet Dagestani Arabic education to include rhetoric and logic subjects in curricula, filling the need of using language to communicate, in written and oral terms, effectively and persuasively, and to understand the implicit and explicit meanings of sacred texts. There are multiple copies of tracts in logic and rhetoric written by representatives of the Caucasian Islamic scholarship that are found inserted amidst the textbooks of the classical period literature such as Tahthib al-Mantiq wal Kalam of the Imam al-Taftathani (d.1390), Hatha Nu'man of Sheikh Said al-Shirwani who devoted his work to the commentary on Isaghuji. We have at our disposal copies of paper notes devoted to mantiq written by two Dagestani scholars Dawud al-Usisha (d.1757) and Hasan al-Kudali (d.1795) in the collection of manuscript (MS Garrett Yahuda 5206A/Mach 3856).

It is very important to know that Arabic literature was accessible to limited circle of people and had no mass readership. Therefore, with the creation of the Dagestani written language based on the Arabic script Ajam, local literature had a considerable impact on the masses. The wave of Ajamic literature flourished in Dagestan as the most popular form of Islamic literary tradition in local languages, particularly in Avar, from the second half of the $18^{\text {th }}$ to the $20 \mathrm{~s}$ of the $20^{\text {th }}$ centuries by which time Latin, subsequently replaced by Cyrillic, letters through Russian education had found a home in the region. It would be of interest to state that I have identified some Ajamic texts in scattered forms in various manuscripts of Shamil's Library at Princeton University library. Content of the Ajamic texts written in Avar language is related to the Islamic culture and teachings. 




Page from Ajamic manuscript on paper, from Dagestan, showing part of the Avar written language (MS Garrett Yahuda 5192/Mach 3485)

Regarding the correspondence, almost all was composed in Arabic by Dagestani scholars, rulers of the khanates, heads of the jama'ats, etc. In the Garrett Yahuda Collection, Dagestani Islamic manuscripts contain multiple copies of letters placed between the folios, sometimes glued to the pages. These documents provide rich information on historical events, interaction between ruler and jama'at, traditional relationship amongst the mountaineers, and present valuable additional materials for researchers in different fields of the Caucasian Studies. (MS Garrett Yahuda 5090/Mach 399; Garrett Yahuda 5222/Mach 3589; Garrett Yahuda 5753/Mach 716; Garrett Yahuda 3214/Mach 3545; ff. 70-81).

\section{Conclusion}

The Princeton collection of manuscripts appears before us as a valuable monument of Muslim culture and science that characterized a level of education up to the late nineteenth century in Dagestan. These are but a few notes on the types of works listed in this article. The Dagestani Islamic manuscripts provide us with the opportunity to ask many questions about the history of the Arabic literary culture in the Caucasus. In the pre-Soviet era, there had been a longstanding tradition of book production, consumption and circulation in Dagestan. The Caucasian manuscripts in Princeton today help us to portray the scholarship with very different genres of writing of the books. The manuscripts serve to bring to the fore differences and commonalities relative to our own time, and inspire us to reflect on the world of ideas that circulated in and around Dagestan in the past. These works are very important both for the studying Dagestani literature and more profound understanding of the literary and cultural connections of this region's peoples. 


\section{References and Endnotes}

1 Research for this paper was mainly conducted through the Fulbright Scholar Program on the spot during the academic year 2010-2011. My special gratitude goes to Michael Reynolds, Professor of the Department of Near Eastern Studies, who invited me to carry out the research work and cooperated with me from the very beginning. Through the Fulbright Scholar Program I enriched my scientific potential and personal experience making different contacts with American colleagues, which turned out to be very fruitful and sustained.

2 The Princeton Firestone Library website: http://firestone.princeton.edu/

3 Princeton has the largest collection of Islamic manuscripts in North America and one of the finest such collections in the Western world.

4 The volume contains the description of Arabic manuscripts in the collection that originally belonged to Abraham S. Yahuda (1877-1951). This collection was acquired by Princeton University Library in 1942 through the generosity of two graduates of Princeton, the late Robert Garrett, Class of 1897, and his brother, the late John Garrett, Class of 1895.

5 Rudolf Mach was curator of the Near East Collections, Princeton University Library (1955-1977) and a professor in the Department of Near Eastern Studies until his death in 1981.

6 Rudolf Much, Catalogue of Arabic Manuscripts (Yahuda Section) in the Garret Collection Princeton University Library Princeton Studies on the Near East: Princeton University Press, 1977.

7 M.S. Saidov, Dagestan literature in the $18^{\text {th }}-19^{\text {th }}$ centuries in the Arabic language // Works of 25-th International congress of the Orientalists, Moscow, 1963 (In Arabic); I. Krachkovskii. Arabian literary in the North Caucasus, in: Izbraniye Sochineniya. M., 1960.Vol.6; M. Gaidarbekov, Anthology of the Dagestan scholars (unpublished) 1970-71 // Manuscript Library of the Institute of History of Dagestan Scientific Center of the Academy of Sciences of Russia (In Arabic) F.3 Op.1. D. 129; M. Gaidarbekov, Anthology of the Dagestan poetry in Arabic (unpublished) 1965 // Manuscript Library of the Institute of History of Dagestan Scientific Center of the Academy of Sciences of Russia (In Arabic) F.3 Op.1. D. 170; A.R. Shikhsaidov, T.M. Aitberov, G.M. Orazaev. Dagestanskiye istoricheskiye socineniya (Dagestan Historical works), Moskva, 1993; Kh. Omarov. 100 pisem Shamily (100 letters of Shamil)//. Vvedenie, teksti, per. s Arab. Kmmentarii, primechaniya, I ukazateli. Makhachkala, 1997; D. Alkhasova, Dawud-khajhi al-Usishi: Jhizn I tvorcheskoye naslediye (Dawud -khadjhi al-Usishi: Life and creative legacy), Makhachkala, 2005

8 Magomed Gizbulaev, Abu Bakr-khajhi iz Aymaki: Jhizn, tvorchestvo I nauchnoye naslediye (Abu Bakr from Aymaki: Life, Creative activity and Scholarly legacy), Makhachkala, 2005.

9 M. Kemper, A. Shikhsaidov, N. Tagirova, The library of Imam Shamil, in Princeton University Library Chronicle. Vol. LXIV. Number I. Autumn, (2002): 121-140; Michael Kemper und Amri R. "Sixsaidov Die Islamgelehrten Daghestans und ihre arabischen Werke," in: Muslim Culture in Russia and Central Asia, Vol. 4. Berlin, 2004

10 See Stefan Reichmuth, "The Interplay of Local Developments and Transnational Relations in the Islamic World: Perceptions and Perspectives," in Muslim Culture in Russia and Central Asia from the 18 to the Early 20 Centuries. Vol.2: Inter-Regional and Inter-Ethnic Relations, Ed. by Anke von Kugelgen, Michael Kemper, Allen J. Frank. Berlin, 1998.

11 Willard Sunderland, "The Caucasian Tangle," in Kritika 7 (2006) : 111-122. 
12 Michael Kemper, "The North Caucasian Khalidiyya and ,Muridism':

Historiographical Problems", in Journal for the History of Sufism vol. 5 (2006), pp.111-126

13 Derbend, which after its islamization with adjacent territories was renamed by Arabs as Bab al-Abwab and thus became the first firm center of academic and educational traditions in today's Russia.

14 See Kh. Donogo, Daniyal-Bek: Sultan Elisuiskii, in: http://gazavat.ru/personalies2.php?people $=38$

\section{Selected Bibliography}

1. "Ajwibah 'an as'ilat al-Derbendi" and "Ajwibah 'an as'ilat Mahdi Khan alShamkhali" of Said al-Harakani (MS Garrett Yahuda 2867/Mach 2645)

2. Ajamic texts written in Avar language is related to the Islamic culture and teachings. (MS Garrett Yahuda 5068/Mach7; Garrett Yahuda 2862/Mach 1443; Garrett Yahuda 5192/Mach 3485)

3. al-Jawahir al-rafi'a fi haqqiyyat madhab ahl al-Sunnah wa-radd shubuh alShi'a(The Lofty Jewelry in the Truth of Ahl al-Sunnah, and Refutation of the Shia Ambiguity) (MS Garrett Yahuda 2867/Mach 2645)

4. Alkhasova, D. Dawud-khajhi al-Usishi: Jhizn I tvorcheskoye naslediye (Dawud khadjhi al-Usishi: Life and creative legacy), Makhachkala, 2005.

5. al-Mafrud 'ala muaddi al-furud min 'ilm at-Tawhid wa rubi' al-'ibadah (The Obligatory Knowledge about the Concept of the Oneness and Worship Required to know by an Incumbent) (MS Garrett Yahuda 1177/Mach 1698)

6. al-Manzumah fil al-kabair (The Poem on Major Sins) (MS Garrett Yahuda 5438/Mach 2033)

7. al-Takhmis a'la lil qasidah al- 'ulya of 'Abbas Fawzi Afandi al-Dagestani (d.?) (MS Garrett Yahuda 3040/Mach 4228)

8. Durrat al-nafisah (The Precious Pearl) (MS Garrett Yahuda 2867/Mach 2034)

9. Gaidarbekov, M. Anthology of the Dagestan poetry in Arabic (unpublished) 1965 // Manuscript Library of the Institute of History of Dagestan Scientific Center of the Academy of Sciences of Russia (In Arabic) F.3 Op.1. D. 170

10. Gaidarbekov, M. Anthology of the Dagestan scholars (unpublished) 1970-71 // Manuscript Library of the Institute of History of Dagestan Scientific Center of the Academy of Sciences of Russia (In Arabic) F.3 Op.1. D. 129

11. Gizbulaev, Magomed. Abu Bakr-khajhi iz Aymaki: Jhizn, tvorchestvo I nauchnoye naslediye (Abu Bakr al-Aimaki: Life, creative activity and scholarly legacy), Makhachkala, 2005. http://gazavat.ru/personalies2.php?people $=38$

12. I. Krachkovskii. Arabian literary in the North Caucasus, in: Izbraniye Sochineniya. M., Vol.6 1960.

13. I'lam at-Tilmiz bi ahkam an-Nabiz (Notification to a Student with regard to the Statements on Millet Beer) (MS Garrett Yahuda 5080/Mach 2090)

14. Kemper, M. and A. Shikhsaidov, N. Tagirova. "The library of Imam Shamil", in Princeton University Library Chronicle. Vol. LXIV. Number I. Autumn, (2002): 121-140

15. Kemper, Michael. “The North Caucasian Khalidiyya and ,Muridism': Historiographical Problems," in Journal for the History of Sufism vol. 5 (2006), pp.111-126 
16. Kitab 'ilm al-faraiz thumma al-Munabbihat qissah 'an al-Mi'raj thumma bayan alAsrar(The Book of Mandatory Knowledge) copied by Isa b. Musa b. Isa al-Ihali (MS Garrett Yahuda 2308/Mach 2037)

17. Mankhul Maghazi (The Chosen Campaigns) (MS Garrett Yahuda 3133/Mach 4549)

18. mantiq written by two Dagestani scholars Dawud al-Usisha (d.1757) and Hasan alKudali (d.1795) in the collection of manuscript (MS Garrett Yahuda 5206A/Mach 3856)

19. Much, Rudolf. "Catalogue of Arabic Manuscripts (Yahuda Section)." In the Garret Collection Princeton University Library Princeton Studies on the Near East: Princeton University Press, 1977

20. Muhimmat al-ma'arif al-wajibah 'ala l-'ibad fi umur al-muta'alliqah bil mabda' wal $m a$ 'ad (The Obligatory Knowledge upon Servants about Issues pertained to the Present World and Hereafter) of 'Ali b. Ibrahim al-Dagestani (d.18 ${ }^{\text {th }}$ century) (MS Garrett Yahuda 3828/Mach 2574)

21. Nuskhah jadidah fil umur al-muhimmah" (MS Garrett Yahuda 4190/Mach 2036)

22. Nuskhah jadidah fil umur al-muhimmah" (MS Garrett Yahuda 4190/Mach 2036)

23. Qasidah munajat al-Imam Shafi' $i$ (Talking in Secret with Imam al-Shafi'i) and Qasidah ya Rasulillah (MS Garrett Yahuda 1069/Mach 4162)

24. Reichmuth, Stefan. "The Interplay of Local Developments and Transnational Relations in the Islamic World: Perceptions and Perspectives." in Muslim Culture in Russia and Central Asia from the 18 to the Early 20 Centuries. Vol.2: Inter-Regional and Inter-Ethnic Relations. Ed. by Anke von Kugelgen, Michael Kemper, Allen J. Frank. Berlin, 1998.

25. Risalah al-Shareifah (The Noble Message) (MS Garrett Yahuda 2867/Mach 2034)

26. Risalah fi 'ilm al- 'Arud (MS Garrett Yahuda 5206A/Mach 3856)

27. Saidov, M.-S. Dagestan literature in the $18^{\text {th }}-19^{\text {th }}$ centuries in the Arabic language // Works of 25-th International congress of the Orientalists. Moscow,1963 (Arabic)

28. Sharh al-Shihab (Commentary on Shihab) (MS Garrett Yahuda 3402/Mach 619)

29. Shikhsaidov, A.R. T.M. Aitberov, G.M. Orazaev. Dagestanskiye istoricheskiye socineniya (Dagestan Historical works), Moskva, 1993.

30. Sunderland, Willard. "The Caucasian Tangle." in Kritika 7 (2006):111-122. 